DOI https://doi.org/10.30525/978-9934-26-075-9-8

\title{
МЕТОД ЗУПИНКИ НОСОВОЇ КРОВОТЕЧІ ЗА ДОПОМОГОЮ БАЛОННОЇ ГІДРОТАМПОНАДИ У ХВОРИХ НА ФОНІ ПРОВЕДЕННЯ АНТИТРОМБОТИЧНОЇ ТЕРАПІЇ
}

\author{
Гарюк Г. I. \\ доктор медичних наук, професор, \\ завідувач кафедри оториноларингології та дитячої \\ оториноларингології \\ Харківська медична академія післядипломної освіти \\ Почусва Т. В. \\ доктор медичних наук, \\ професор кафедри оториноларингології та дитячої \\ оториноларингології \\ Харківська медична академія післядипломної освіти
}

Бичкова Н. С.

асистент кафедри хірургічних хвороб

Харківський національний університет імені В. Н. Каразіна м. Харків, Україна

Актуальність. В даний час авторами констатується неухильне зростання кількості пацієнтів з патологією серцево-судинної системи, які потребують проведення антитромботичної терапії. За даними ВОЗ в урбанізованих країнах більше половини летальних випадків пов'язано 3 хворобами, обумовленими тромбозом магістральних венозних стволів, коронарних та церебральних артерій. Проведення антитромботичної терапії показало свою високу ефективність в первинній та вторинній профілактиці серцево-судинних ускладнень $[1,2,3]$.

На фоні прийому антикоагулянтів та дезагрегантів завжди вище ризик розвитку геморагічних ускладнень. Антитромботична терапія підвищує ризик виникнення носових кровотеч (НК) та по даним авторів кількість стаціонарних хворих з НК, котрі знаходяться на антитромботичній терапії, складає від $29 \%$ до 48\% $[4,5,6]$.

Особливості місцевих гемостатичних заходів при НК на фоні антитромботичної терапії мало вивчені та маються одиничні повідомлення про ефективність різних методів зупинки НК у даної категорії хворих [7, 8, 9]. Жоден з нині існуючих методів зупинки НК не 34 
позбавлений недоліків та не володіє 100\% ефективністю. У зв'язку з цим актуальним залишається удосконалення способів зупинки НК, що володіють достатньою ефективністю, швидкістю та простотою виконання, доступністю та створюють мінімальний дискомфорт для хворих.

Мета роботи. Розробка способу зупинки НК, що дозволяє поєднати декілька видів впливу на кровоточиву ділянку.

Матеріали та методи. Нами запропоновано комбінований метод зупинки НК, який включає до себе використання двокамерного гідротампона власної конструкції в поєднанні з гелем «Нозохем» та термічним впливом. Перевагами запропонованого гідротампона $€$ наявність носового дихання (основою тампона $є$ інтубаційна трубка), відсутність травмування слизової оболонки (що зменшує ризик рецидиву НК), відсутність больових відчуттів при введенні та видаленні тампона. Перед тампонуванням проводиться попереднє введення в порожнину носа гелю «Нозохем». При введенні гелю в порожнину носа, гель м'яко обволікає слизову оболонку і судину, яка кровоточить. Гідротампон з обережністю вводиться уздовж дна порожнини носа на всю довжину до упору в звід носоглотки за допомогою носового дзеркала і штикобразного пінцета. Потім задній балон гідротампона заповнюється нагрітим до $45-48^{\circ} \mathrm{C}$ фізіологічним розчином (селективна гіпертермія), передній балон гідротампона - охолодженим фізіологічним розчином до $4-8^{\circ} \mathrm{C}$ (селективна гіпотермія) за допомогою одноразового шприца, який приєднується до клапанного пристрою, при цьому обтуруя порожнину носа і здавлюючи кровоточиві ділянки слизової оболонки. Тривалість тампонади становила 48-72 години, після чого проводиться евакуація фізіологічного розчину 3 балонів шприцем i видалення гідротампона. Запропонований нами метод зупинки НК застосовувався у 104 хворих, у яких НК виникли на фоні проведения антитромботичої терапиї.

Результати. У 100 (96,1\%) хворих запропонований нами метод забезпечив ефективну зупинку НК, середня тривалість тампонади носа складала 52,2 $\pm 5,1$ години. Час повної зупинки кровотечі після тампо-

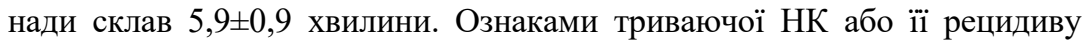
(неповний гемостатичний ефект) було фарбування задньої стінки глотки кров’ю, що стікає та підтікання з присінку носа. В період тампонування одиничні епізоди НК мали місце у 3 (2,9\%) хворих. 3 них у 2 хворих кровотеча виникла у першу добу після тампонади та у одного - на другу добу. В усіх випадках кровотечі були незначні та обумовлені недостатнім роздуванням балонів гідротампона. За для ліквідації НК у цих випадках вжиті наступні заходи: видалення гідротампона 3 порожнини носа, видалення геморагічних згустків 3 порожнини носа за допомогою 
електроаспіратора та повторне тампонування порожнини носа до повної зупинки НК. У одного $(0,9 \%)$ хворого спостерігався рецидив НК після видалення тампона. 3 ціллю ліквідації рецидиву НК проведена повторна тампонада порожнини носа. Таким чином загальна кількість рецидивів НК склала 4 (3,8\%)

Висновки. Таким чином, запропонований нами метод зупинки НК $\epsilon$ простим, ефективним, фізіологічним та може застосовуватися як метод вибору зупинки НК у хворих на фоні проведення антитромботичної терапії.

\section{Література:}

1. Дячук Д.Д., Мороз Г.З., Гідзинська І.М., Ласиця Т.С. Поширеність факторів ризику серцево-судинних захворювань в Україні:сучасний погляд на проблему. Украӥнський кардіологічний журнал. 2018. № 1. С. 91-101.

2. Кудрявцева Л. І., Філіппов Е. В. Стратегія ведення пацієнта з ФП з метою зниження ризику тромбоемболічних ускладнень. Атеротромбоз. 2019. № 1. C. 44-52.

3. Connolly S. J., Wallentin L., Ezekowitz M. D., Eikelboom J. et al. The long-term multicenter observational study of dabigatran treatment in patients with atrial fibrillation (RELY-ABLE). Circulation. 2013. Vol. 128. P. 237-243.

4. Бабин С.М. Про особливості тактики ведення і прогнозуванні ускладнень захворювань серцево-судинної системи у хворих з носовою кровотечею. Рос.оторінолар. 2016. № 6 (85). С. 103-106.

5. Stadler R.R., Kindler R., Holzmann D., Soyka M.B. The long-term fate of epistaxis patients with exposure to antithrombotic medication. Eur. Arch. Otorhinolaryngol. 2016. Vol. 273. P. 2561-2567.

6. Buchberger A.M.S., Baumann A., Johnson F. et al. The role of oral anticoagulants in epistaxis. Eur. Arch. Otorhinolaryngol. 2018. Vol. 275(8). P. 2035-2043.

7. Soyka M.B., Rufibach K., Huber A., Holzmann D. Is severe epistaxis associated with acetylsalicylic acid intake? Laryngoscope. 2010. Vol. 120. P. 200-207. 